\title{
INNOVATIVE-THEMATIC BASED INTEGRATED SCIENCE LEARNING ON NATURAL DIVERSITY THEME TO IMPROVE STUDENTS' CRITICAL THINKING SKILLS IN JUNIOR HIGH SCHOOL
}

\author{
Indarini Dwi Pursitasari $^{\varpi 1}$, Siti Nuryanti ${ }^{2}$, Amran Rede ${ }^{2}$ \\ ${ }^{1}$ Universitas Pakuan, Jl. Pakuan PO. BOX 452 Bogor 16143 \\ ${ }^{2}$ Universitas Tadulako, Kampus Bumi Tadulako, Tondo PALU 94119
}

\section{Article Info}

Received April 2018

Accepted May 2018

Published July 2018

Keywords:

Integrated Science Learning,

Thematic, Innovative, Critical

thinking skills

\begin{abstract}
Critical thinking skills should be trained and practiced in the learning process. This study aimed to describe the use of Innovative-Thematic Based Integrated Science (ITBIS) Learning Program to improve critical thinking skills of junior high school students in Palu. The study conducted in the $7^{\text {th }}$ grade from one of Palu public schools and one of Palu private schools. Data were collected by observation sheet of learning performance and students activity, also test instrument for measuring students' critical thinking skills. The data of learning performance and students activity were analyzed quantitatively, whereas the data of critical thinking skills were analyzed using descriptive and inferential statistics. The result showed that 1TBIS learning can be done well either in public school and private school with average $98,03 \%$ and $90,20 \%$ respectively. ITBIS learning also improve students activity in the learning process. The average of critical thinking skills improvement (N-gain) was 68\% (public school) and 63\% (private school), and there were no significant differences between both of them. It showed that ITBIS learning can be used to build critical thinking skills of junior high school students.
\end{abstract}

${ }^{\square}$ Corresponding author:

Indarini Dwi Pursitsari

${ }^{1}$ Program Pascasarjana Universitas Pakuan

E-mail: indarini.dp@unpak.ac.id 


\section{INTRODUCTION}

Indonesia has abundant natural resources. Each island in Indonesia has a typical wealth and natural resources. These were located in Central Sulawesi also diverse and high potential to be used by the public. Utilization of natural resources needs human resources (HR) quality.

HR Quality is not only based on intellectual ability but also need to be skilled. The importance of skills in life has been responded to by the government through the curriculum 2013. Four core competencies in the curriculum where students must achieve in 2013 is the competence of religious attitudes / spiritual, social attitudes, knowledge, and skills. Skills in 2013 curriculum emphasize not only physical skills but also thinking skills.

One type of thinking skills is critical thinking skill. A person who thinks critically does not mean the rebels. People who think critically will scrutinize and resolve the problems it faces well. It is, therefore, critical thinking skills necessary to build early in an effort to improve the ability of HR to be individuals of high intellectual and critical to potentially manage natural resources properly and wisely.

Critical thinking skills can be developed through learning Natural Sciences (IPA) in the Junior High School (SMP). Learning science in junior high school in 2013 curriculum is based on the thematic integrative. Science lessons in junior high schools in the curriculum 2013 based integrative thematic. Integral science learning with a constructivist-based learning strategy (Bimbola \& Daniel, 2010) and scaffolding strategy (Alake \& Ogunseemi, 2013) can improve the performance and achievement of junior high school students

In fact, teaching science to junior high school students in the town of Palu still ongoing separate and it is not thematic (Pursitasari, et al., 2013). Science teachers' educational background is biology and physics, so they do not believe themselves to teach science in integrated manner. In addition, science teaching also not provides an opportunity for students doing practical work. Teachers are not utilizing science laboratories for practical activities as a vehicle to build knowledge and develop psychomotor skills and thinking skills. Teachers have not utilized the science laboratory for practical activities as a vehicle for building knowledge and developing psychomotor skills and thinking skills. According to Kelly and Finlayson (2009), lab work in the laboratory provides opportunities for students to improve skills, mastering concepts, and experimental processes. Practical activities also facilitate students to experiment, solve problems, create creativity, and improve understanding (Cooper \& Kerns, 2006)

Based on the existing problems and demands of the curriculum at the junior secondary level, so it has been structured learning program of innovative thematic-based Integrated Science (ITBIS). The learning program is equipped with textbooks, as well as devices and media animation for learning process (Pursitasari, et al., 2014). The results of the validation expert and teacher as a user of the learning program showed the average score of lesson plan assessment was 3.4 ; instruments critical skills was 4.2 ; instructional media was 4.0; and textbooks was 4.4 (Pursitasari, et al., 2014). Based on the results and the acquisition of predetermined criteria, the lesson plan, the instrument of critical skills, instructional media, and textbooks are valid and practical nature.

The ITBIS learning programs have also been tested on a limited basis on subthemes Characteristics of Natural Diversity (Pursitasari, et al., 2015). The results showed the critical thinking skills of students increased by $\mathrm{N}$-gain of 0.52 (medium category) and the character of students with $\mathrm{N}$-gain of 3.1 (good categories). This means developed learning ITBIS can train critical thinking skills. Critical thinking is related to the ability of students to connect, compare, classify, analyze, and evaluate an object (Zohler $\&$ Pushkin, 2007).

Based on the problems and the research results, then ITBIS learning programs need to be utilized in science teaching in secondary schools in the city of Palu. The purpose of this study was to describe the use of ITBIS learning programs in developing critical thinking skills of junior high school students in the city of Palu.

\section{METHODS}

The experiment was conducted in class VII SMP Negeri 2 Palu and SMP Gamaliel Palu with Only Pretest-Posttest Control Group Design. Selection of these two schools because of the ability of students and teachers in the classroom has a relatively equal ability. Students were administered critical thinking skills test before and after learning ITBIS. During the learning process, the researchers carried out 
observation of enforceability of the ITBIS learning and student activities, also conducted an assessment of the student's character. The data of ITBIS learning process was calculated by percentage and the data of student activities were quantitatively classified into 1-5 scale (1,0-1,80: worst; 1,81-2,60: bed; 2,61-3,40: quite good; 3,41-4,20: good; and 4,21-5,00: very good). The data of critical thinking skills was analyzed statistically descriptive include the highest score, the lowest score, mean, standard deviation, and $\mathrm{N}$-gain. The independent t-test was conducted to test the significance of differences between the mean enhancement of critical thinking skills of students in class VII SMP Negeri 2 Palu and Gamaliel Palu.

\section{RESULTS AND DISCUSSION}

During the implementation of ITBIS in science learning, researchers carried out observations of the teachers activities in SMPN 2 Palu and SMP Gamaliel Palu. The observation result of enforceability of the learning undertaken by teachers in ITBIS learning was presented in Figure 1.

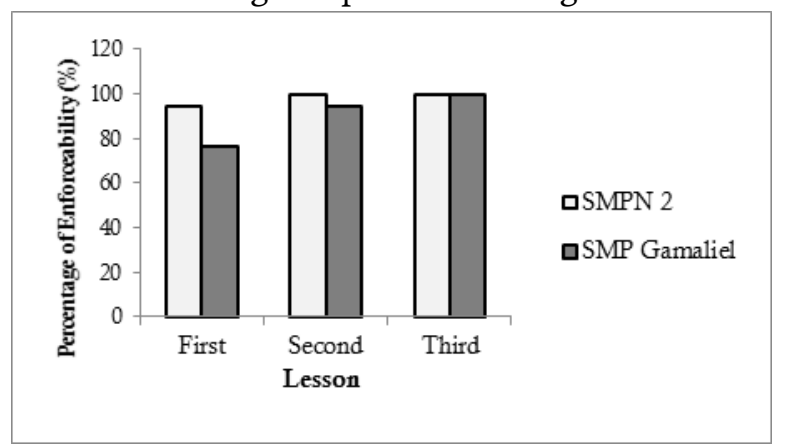

Figure 1. Percentage of Enforceability of ITBIS Learning

The result of utilization of ITBIS learning program in SMP Negeri 2 and SMP Gamaliel Palu showed science teachers at both schools can implement ITBIS learning very well. This can be seen from the observation of the enforceability ITBIS learning at the last meeting which reached $100 \%$. Teachers seem more creative in implementing science learning and able to facilitate students to ask and answer a teacher's question with a simple explanation and detailed description. Research results of Min et al. (2012) showed the teacher in thematic learning more planned thematic learning activities, systematic, active, and attractive. Results of the study also showed that the thematic learning more easily implemented and can stimulate the creativity of teachers. Teachers can develop learning becomes more meaningful and able to encourage students to study hard and be motivated. The ability of teachers in implementing the ITBIS learning impact on increasing student activity in learning. ITBIS Learning provides an opportunity for students to be actively involved in learning through collaborative discussions. ITBIS learning which also uses multimedia can increase interest and attention, so that students are more eager to follow the learning process. The use of multimedia helps students to gain more efficient knowledge as well as improve interaction between teachers and students (Malik \& Agawal, 2012).

The ability of teachers in implementing the ITBIS learning has impact on the increased activity of students in learning. ITBIS learning given students the chance to be actively involved in learning through collaborative discussion. ITBIS learning was also used multimedia which capable to increase students interest and attention so that students were more eager to follow the learning process. Students activities in class VII SMP Negeri 2 Palu and SMP Gamaliel during the ITBIS learning showed an increase in average score of activity of the first, second, and third meeting (Figure 2).

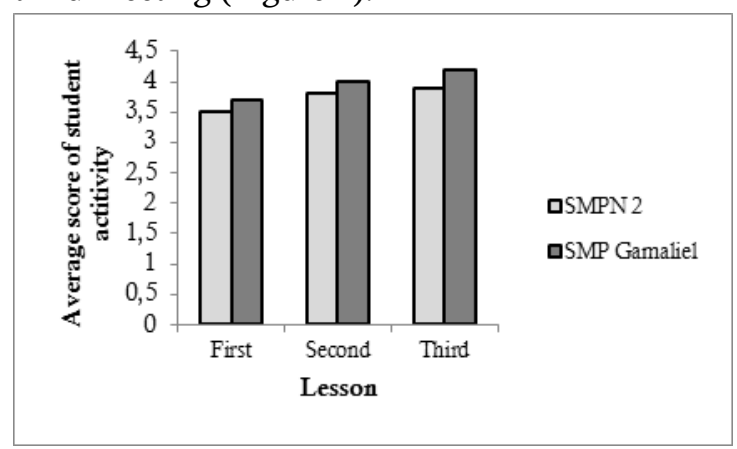

Figure 2. The Average of Students Activities in ITBIS Learning

When compared with SMP Negeri 2 Palu, the average score of students of SMP Gamaliel was better. This condition can be caused by the number of students who asked or answered questions, more interactive group discussion, and better student discipline. Besides it, the number of students in class VII Gamaliel less than students in SMP Negeri 2, so the teacher was easier to manage students to be actively involved in the learning process.

The impact of high student activity through the use of ITBIS learning with problem based learning model is the increasing of students' 
thinking skill. This is in line with the results of Anazifa and Jukri (2017) research that problembased learning (PBL) and project-based (PjBL) can improve students' critical and creative thinking skills. Table 1 showed the differences between the average value, standard deviation, and $\mathrm{N}$-gain students critical thinking skills of class VII SMP Negeri 2 and SMP Gamaliel Palu were enough category. Learning in ITBIS program facilitated students to learn independently in the group. This is similar to the results of research Albaar (2015) which concluded that students critical thinking skills can be improved through self-directed learning models based on information technology. Independent learning in groups has a significant effect on improving learning outcomes and student attitudes (Ajaja, 2010) and critical thinking (Kopzhassarova, 2016).

Independent learning have significant effect on critical skills, creativity, curiosity, and the satisfaction of students in learning (Edmondson, et al., 2012).

Tabel 1. Description of Students Critical Thinking Skills

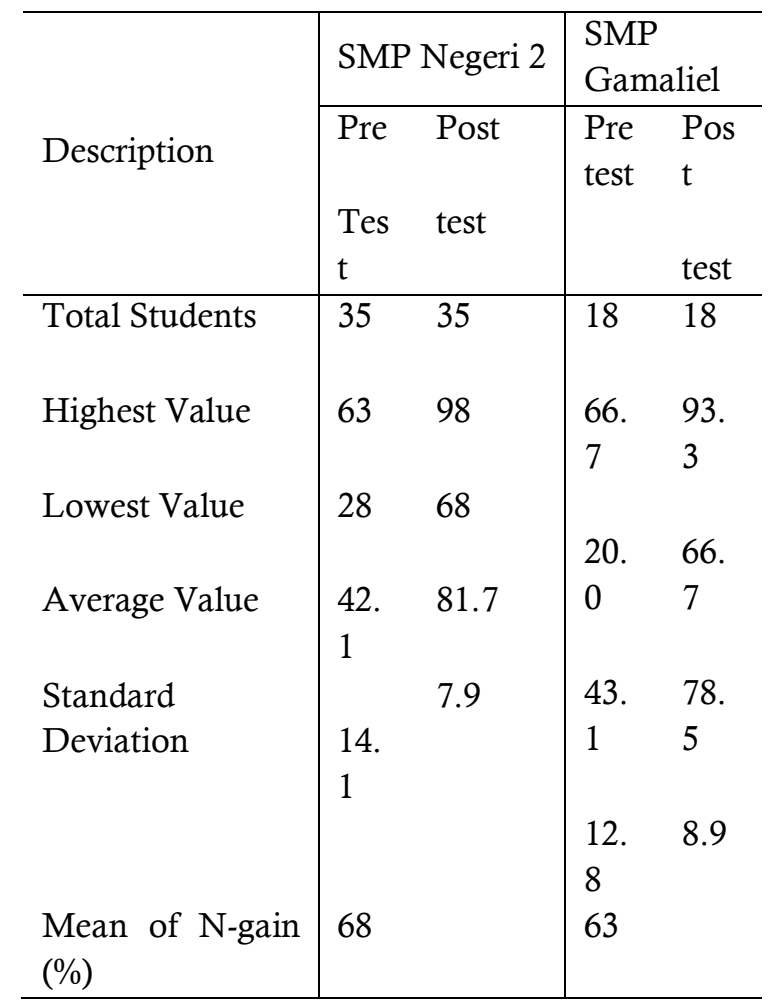

ITBIS learning combines science concepts in a particular theme. The themes in the study is Natural Diversity. According to Rose (2009), thematic-based integrated learning gives students the chance to understand a concept, linking concepts with each other concepts, as well as classifying these concepts. Students' ability to connect with the concept of one another concept that will result in the student's ability to compare, understand the problem as a whole, understand the concept of a variety of viewpoints, able to solve problems, and provide a detailed explanation (Klein, 2005). Phase problem solving begins with formulating the question, at the stage of observation and investigation, students are actively involved in implementing the principles and concepts that understanding becomes more meaningful and significant (Leonard, 2012). Students are also trained to look for similarities or differences based on the observation and investigation, as well as capable to analyze the observation results and draw conclusions. Critical thinking skills is a process that is focused and clear in performing mental activities such as solving problems, making decisions, and conduct scientific research (Johnson, 2009). The significance of differences between the average of students critical thinking skills was determined by using the $t$ test after test for normality and homogeneity (Table 2).

Table 2. Results of Statistical Test of Students Critical Thinking Skills Improvement

\begin{tabular}{lll}
\hline & $\begin{array}{l}\text { SMPN } \\
2\end{array}$ & $\begin{array}{l}\text { SMP } \\
\text { Gamaliel }\end{array}$ \\
\hline $\begin{array}{l}\text { Normality Test } \\
\text { (Kolmogorov- }\end{array}$ & 0.088 & 0.200 \\
$\begin{array}{l}\text { Smirnov) } \\
\text { Homogeneity Test } \\
\text { (Uji Levene's) }\end{array}$ & 0.994 (homogen) \\
p-value (Sig.) & $\begin{array}{l}0.126 \quad \text { (not } \\
\text { significant) }\end{array}$ \\
\hline
\end{tabular}

Table 2 shows normal distributed data and homogeneous. Meanwhile, the test results demonstrated the value of probability or significance of students critical thinking skills in SMP Negeri 2 Palu and SMP Gamaliel ( $\mathrm{p}=$ 0.126 ) was greater than the value of sig. $\alpha=$ 0.05 , so that the null hypothesis $\left(\mathrm{H}_{0}\right)$ is accepted. This means that there are no differences between the average improvement of students critical thinking skills in both schools significantly. This means ITBIS learning program can be used in the public schools and private schools. This shows the ability to think critically can be trained and provided for both students in public 
and private schools with supported by adequate facilities and infrastructure. Critical thinking skills can be trained in science learning through activities such as laboratory work, collaborative discussions, asking questions, proposing problem, as well as the provision of home assignments. It's also expressed by some researchers such as implementation of problem-based learning (Duran \& Dökme, 2016 dan Anazifa \& Jukri, 2017), project based learning (Anazifa \& Jukri, 2017), inquiry learning (Quitadamo, et al, 2017), information and Technology-based learning (Albaar, 2015), and cooperative learning (Nezami, et al, 2013) to promoting critical thinking skill.

\section{CONCLUSION}

Based on the results, it can be concluded that ITBIS learning can be implemented in both public and private schools, can increase the activity of students in learning, and improve students' critical thinking skills class VII of Junior High School in the city of Palu.

\section{ACKNOWLEDGMENT}

The author would like to thank the Director of Research and Community Services through the Assignment Agreement Implementation Leading Higher Education Research Grants Fiscal Year 2015 Number: 171.L/UN28.2/PL/2015.

\section{REFERENCES}

Ajaja, O. P., (2010). Effects of cooperative learning strategy on junior secondary school students achievement in integrated science. Electronic Journal of Science Education. 14(1): 1-18

Alake, E. M. M. \& Ogunseemi, O. (2013). Effects of scaffolding strategy on learners' academic achievement in integrated science at the junior secondary school level. European Scientific Journal, 9(19): 149-155

Albaar, Z. (2015). Pengaruh self-directed learning berbasis teknologi informasi terhadap keterampilan berpikir kritis dan kemampuan belajar mandiri siswa kelas XI IPA di SMA Negeri 1 Palu. Tesis S2 pada Universitas Tadulako. Tidak diterbitkan.

Bimbola, O. \& Daniel, O. I. 2010. Effect of constructivist-based teaching strategy on academic performance of students in integrated science at the junior secondary school level. Educational Research and Reviews.5 (7): 347-353
Cooper, M. M. \& Kerns, T. S. (2006). Changing the laboratoty: effects of a laboratory course on students' attititudes and perception. Journal of Chemical Education. 83, (9), 1356-1361. DOI: $10.1021 /$ ed083p1356

Edmondson, D. R., Artis, A. B., \& Boyer, S. L. (2012). Self-directed learning: a meta analytic review of adult learning constructs. International Journal of Education Research, 7(1): 40-48. Retrived from http://debdavis.pbworks.com/w/file/fetch 196898755

Johnson, E. B. (2009). Contextual teaching and learning. Jakarta: Mizan.

Kelly, O. \& Finlayson, O. (2009). A hurdle too high? Students' experience of a PBL laboratory module. Chemistry Education Research and Practice., 10, 42-52. DOI: 10.1039/B901459B

Klein, J.T. (2005). Integrative learning and interdisciplinary studies. Peer Review. 7: 810. Retrived from http://www.academia.edu/755632

Kopzhassarova, U., Akbayeva, G., Eskazinova, Z., Belgibayeva, G., \& Tazhikeyeva, A. (2016). Enhancement of students' independent learning through their critical thinking skills development. International Journal Of Environmental \& Science Education. 11(18):11585-11592. Retrived from http://www.ijese.net/makale/1619

Leonard, J. B. (2012). Integrative learning: A grounded theory. Issues In Integrative Studies. 30. 48-74. Retrived from https://eric.ed.gov/?id=EJ1101062

Malik, S. \& Agarwal, A. (2012). Use of multimedia as a new educational technology tool-a study. International Journal of Information and Education Technology, 2(5): 468-471. DOI: 10.7763/IJIET.2012.V2.181

Min, K. C., Rashid, A. M., \& Nazri, M. I., (2012). Teachers' understanding and practice towards thematic approach in teaching integrated living skills (ILS) in Malaysia. International Journal of Humanities and Social Science. 2 (23): 273-281.

Nezami, N. R., Asgari, M., \& Dinarvand, H. (2013). The effect of cooperative learning on the critical thinking of high school 
students. Technical Journal of Engineering and Applied Sciences. 3(19): 2508-2514

Pursitasari, I. D., Nuryanti, S. \& Rede, A. (2014). Pengembangan program pembelajaran IPA terpadu berbasis tematik inovatif untuk membangun kemampuan berpikir kritis dan karakter siswa SMP Di Kota Palu. Prosiding Seminar Nasional Kimia. Surabaya: Jurusan Kimia FMIPA Universitas Negeri Surabaya.

Pursitasari, I. D., Nuryanti, S. \& Rede, A. (2015). Promoting of thematic-based integrated science learning on the junior high school. Journal of Education and Practice. 6 (20): 97-101.

Quitadamo, I. J., Faiola, C. L., Johnson, J. E., \& Kurtz, M. J. (2017). Community-based inquiry improves critical thinking in general education biology. Life Sciences Education. 7: 327-337,

Rose, M. (2009). Encouraging integrative learning through current event and learning portofolios. Teaching \& Learning Journal. 3(2): 1-7.

Zohler, U. \& Pushkin, D. (2007). "Matching higher order cognitive skill (HOCS) promotion goals with problem based laboratory practice in a fresman organic chemistry course". Chemistry Education Research and Practice. 8, (2), 153-171. 